\title{
Effect of the environment and use of alternative products in the post-harvest of papaya
}

\author{
Kiyotaka Murakami ${ }^{1}$, Andre Freire $\mathrm{Cruz}^{2}$, Marcio de Carvalho Pires ${ }^{3}$, \\ Ivone Midori Icuma ${ }^{4}$, Osvaldo Kiyoshi Yamanishi ${ }^{5}$
}

\begin{abstract}
This study aimed to establish an alternative treatment for post-harvest storage of Papaya (Carica papaya L.), var "Tainung 1" and to control major diseases at this stage. Two storage place were evaluated (room temperature and cold room); Six treatments (Control, Samurai 40ml/201 water, Serenade ${ }^{\circledR} 40 \mathrm{ml} / 201$ water, Sanatizer EUPROOFF ${ }^{\circledR} 10 \mathrm{ml} / 201$ water, EUPROOFF ${ }^{\circledR}+$ Serenade ${ }^{\circledR}+$ Samurai, Serenade ${ }^{\circledR}+$ Samurai), five storage periods $(0,3,6,9$ and 12 days $)$ and three seasons (December, January and February). Fruit weight loss (FWL), color index, number and size of lesions were evaluated and used to calculate the disease incidence and average of disease incidence. The FWL and index color of fruits were more affected by monthly variation than the treatments, especially the Samurai one. The growth of disease incidence were slower under cold room. Among the treatments, the Samurai was the most efficient, but if mixed to others products their efficiency was not observed. These results suggest that the using of Samurai only in cold room conditions can be more effective in control of post-harvest diseases of papaya.

Index terms: Fruit disease, Biocontrol, Cold room, Fungicide, Organic pesticide.
\end{abstract}

\section{Efeito do ambiente e uso de produtos alternativos na pós-colheita do mamão}

Corresponding author: andre@kpu.ac.jp

Received: June 21, 2019 Accepted: April 30, 2020

Copyright: All the contents of this journal, except where otherwise noted, is licensed under a Creative Commons Attribution License.

\section{(cc) $\mathbf{E Y}$}

Resumo - Este trabalho visou a desenvolver um método alternativo para o armazenamento póscolheita de mamão (Carica papaya L.), var. "Tainung 1", e a controlar as principais doenças nesta fase. Foram avaliadas duas condições de armazenamento (temperatura ambiente e câmara fria); seis tratamentos (Controle, Samurai $40 \mathrm{~mL} / 201$ de água, Serenade ${ }^{\circledR} 40 \mathrm{~mL} / 201$ de água, Fungicida EUPROOFF ${ }^{\circledR} 10 \mathrm{~mL} / 201$ de água, EUPROOFF ${ }^{\circledR}+$ Serenade ${ }^{\circledR}+$ Samurai, Serenade ${ }^{\circledR}+$ Samurai); cinco períodos de armazenamento ( $0 ; 3 ; 6 ; 9$ e 12 dias), e três meses (dezembro, janeiro e fevereiro). A perda de massa dos frutos (PMF), a cor, o número e o tamanho das lesões foram avaliados e utilizados para calcular a incidência da doença bem como a média desta incidência. A PMF e a cor dos frutos foram mais afetadas pela variação mensal do que os tratamentos, principalmente o Samurai. O crescimento da incidência da doença foi mais lento em câmara fria. Entre os tratamentos, o Samurai foi o mais eficaz de todos; mas, se misturado a outros produtos, sua eficiência não foi observada. Esses resultados sugerem que o uso do Samurai somente em condições de câmara fria pode ser mais eficaz no controle de doenças pós-colheita do mamão.

Termos para indexação: Doenças em Frutas, Controle Biológico, Câmara fria, Fungicida, Pesticida Orgânico.

\footnotetext{
${ }^{1}$ Master student, Faculdade de Agronomia e Medicina Veterinária, Universidade de Brasília,, Brasília, Brazil. E-mail: kiyotaka063@gmail. com (ORCID 0000-0003-3630-3639)

${ }^{2}$ PhD. Associate Professor, Kyoto Prefectural University,Kyoto, Japan, E-mail: andre@kpu.ac.jp (ORCID 0000-0001-9349-2742)

${ }^{3} \mathrm{PhD}$. Assistant Professor, Faculdade de Agronomia e Medicina Veterinária, Universidade de Brasília, , Brasília, Brazil. E-mail: mcpires@ unb.br (ORCID 0000-0003-2874-8398)

${ }^{4} \mathrm{PhD}$. Visitor Professor, Faculdade de Agronomia e Medicina Veterinária, Universidade de Brasília, , Brasília, Brazil. E-mail: imicuma@ hotmail.com (ORCID 0000-0001-6833-6342)

${ }^{5}$ Dr.Associate Professor, Faculdade de Agronomia e Medicina Veterinária, Universidade de Brasília, , Brasília, Brazil. E-mail: kiyoshi@unb. br (ORCID 0000-0002-2685-0973)
} 


\section{Introduction}

The papaya production in Brazil reached 1.425 million tons in 2016, and 38 thousand tons was exported (FAOSTAT, 2018). Despite the high production and income generated by papaya in this country, a large postharvest losing often occurs (CHITARRA; CHITARRA, 2005). Tropical fruits have a reduced shelf life as compared to other crops (grains and cereals), because they have high moisture content and are easily damaged due to soft texture and high respiratory rates. These characteristics expose them to a large number of diseases that appears during the post-harvest stage as consequence of infections come from the field. Furthermore, in post-harvest fruit losses can occur due to the lack of commercialization or consumption of the product on time (JACOMINO et al., 2002; CHITARRA;CHITARRA, 2005; FONTES et al., 2008).

Anthracnose is considered one of the most important diseases of papaya, caused by Colletotrichum gloeosporioides (Penz), which can also infect other fruits at post-harvesting. Although the harvested fruits do not show diseases symptoms, they can appear at packaging, transportation, maturing and trading phase (CIA, 2005).

In order to preserve fruit quality and avoid postharvest losses, phytosanitary treatment have been, such as hot water, waxes and fungicides to delay the senescence of the fruits (NERY-SILVA, et al., 2001; ZAMBOLIM et al., 2002). After the phytosanitary treatment, the fruits are stored in cold room, under controlled atmosphere (CA) or modified atmosphere (MA). The CA consists in the prolongation of the storage life of the products, through modification and control of the gases in the storage medium, mainly in the reduction of the percentage of $\mathrm{O}_{2}$ and increase of $\mathrm{CO}_{2}$ (AMARANTE et al., 2001).

The conditions for this system implementation depend on the current situation, especially those related to the market, so that the investment can be compensated by an income in a short and/or medium term. In MA storage, the local atmosphere is generally altered by using of plastic films, allowing the $\mathrm{CO}_{2}$ concentration from the product to increase and the $\mathrm{O}_{2}$ concentration to decrease by respiration. In such kind of storage, concentrations of these gases are not controlled, and can range according to time, temperature, film type and respiratory rate of the product. In active MA storage, the atmosphere inside the package is modified during storage by gaseous mixtures, with pre-established concentrations until reaching the equilibrium. Thus, systems with low or high concentrations of $\mathrm{O}_{2}$ may be used in mixtures with other gases, such as $\mathrm{CO}_{2}, \mathrm{CO}$ or $\mathrm{N}_{2}$ (CHITARRA; CHITARRA, 2005).

According to CHITARRA and CHITARRA (2005); CIA et al. (2007), the using of polyvinyl chloride film (PVC) becomes more efficient when it is associated with cooling, since it promotes a considerable increase in the storage life of fruits. Flavoring and sensory quality of many perishable products increases after harvesting and then decays rapidly if the cold storage process is not used. Without this management, deterioration is faster due to the production of heating and the release of $\mathrm{CO}_{2}$ from breathing. Therefore, storage temperature is the most important environmental factor, not only from a commercial point of view, but also by controlling senescence, since it regulates the rates of all associated physiological and biochemical processes. They induce to a respiration reduction, which reduces taste, texture, color and other attributes of product quality (CHITARRA; CHITARRA, 2005). Their efficiency depends basically, on how quickly the product cools, the uniformity of temperature, and relative humidity $(\mathrm{RH})$, which, in the case of papaya the recommendations are $10^{\circ} \mathrm{C}$ and 85 to 90\% RH (SILVA; SOARES, 2001).

According to Oliveira (2000), the fruits ripening are affected by hot water treatments, measured by fruit hardness, membrane and flavor changes, and respiration rate and ethylene production. Immersion of the fruits into thiabendazole and benomyl at room temperature reduces the rot caused by Colletotrichum and other fungi. When fungicidal suspensions are associated with hot water treatment, the control becomes even more efficient. However, European fruit importers are planning to do not accept fruits containing residues of fungicides or other pesticides. The use of chemicals constitutes a serious risk to the environment and human health, mainly due to the presence of toxic waste (ZAMBOLIM et al., 2002 and MORAES et al., 2008).

Biological control is currently one of the alternative options to control plant diseases. Preformed preparations based on different microorganisms or their metabolites are already commercialized in the international and domestic markets (ROMEIRO, 2007). As an alternative to these products, research has shown benefits of using biological agents such as B. subtilis (KRETZCHMAR, 1989; KRETZCHMAR; SANHUEZA 1991; SANHUEZA; BORSÓI, 1991). Although there are few publications in the area of biological control of fruit pathogens in Brazil, most of the research has shown good results. Within this context, it is possible to achieve in a short time the biological control applied in large scale in Brazil. Such methods have succeeded in the United States (PUSEY et al., 1985).

Considering the possibility of preventing diseases with biological agents, this research hypothesized that the application of bioproducts in papaya may confer an increase of storage life. Thus, the objective of this work was to evaluate the effect of alternative products in postharvest conservation of papaya Formosa "Tainung 1" under different storage conditions. 


\section{Materials and methods}

The experiments were conducted at the Laboratory of the Experimental Station of Biology, University of Brasília - DF. The papaya fruits from the 'Formosa' group (Tainung $1 \mathrm{cv}$.) were harvested at different times, December 2017, January and February 2018, in Unai-MG-Brazil, considering the ripening stage 1 (FOLEGATTI; MATSUURA, 2002). After harvesting, the fruits were wrapped in newspaper, packed in plastic boxes, and then transported to the laboratory for further analysis. They were selected based on the appearance (discarding those with lesions or inadequate coloring), in order to standardize the ripening stage and the qualitative aspects of fruits.

The experiment was set in a completely randomized design, with three replicates, with factorial scheme $3 \times 5 \times 2 \times 6$, composed by three seasons (December, January and February); five storage periods $(0,3,6,9$ and 12 days); two storage conditions (inside and outside the cold room); and six treatments (1-control, 2-Samurai $40 \mathrm{ml} / 201$ water, 3-Serenade ${ }^{\circledR} 40 \mathrm{ml} / 201$ water, 4-Sanitizer EUPROOFF® $10 \mathrm{ml} / 201$ water, 5EUPROOFF $\AA$ + Serenade $\AA$ + Samurai, 6- Serenade ${ }^{\circledR}$ + Samurai). The evaluated parameters were mass, shell color (Hunter Lab).

The products used were EUPROOFF®, a sanitizer, whose active principle is Benzalkonium chloride and Didecyldimethyl ammonium chloride; Samurai (Yasaki Co., Japan); and Serenade ${ }^{\circledR}$ (Bayer Co. Germany). Samurai is a bioproduct containing the Bacillus genus produced by liquid separation from compost. Serenade ${ }^{\circledR}$ is a biological pesticide containing B. subtilis QST713.

The fruits were submitted to the following treatments, where the fruits were immersed in solutions followed by air drying: 1 - Control (only water), 2 Samurai $(40 \mathrm{ml} / 201), 3$ - Serenade ${ }^{\circledR}$ solution $(40 \mathrm{ml} / 201)$ followed by EUPROOFF ${ }^{\circledR}(10 \mathrm{ml} / 201), 5$ - EUPROOFF (R) $(10 \mathrm{ml} / 201)$ followed by a mixing of Samurai ( 40 $\mathrm{ml} / 201)+$ Serenade ${ }^{\circledR}(40 \mathrm{ml} / 201)$, and 6 - Mixing of Samurai $(40 \mathrm{ml} / 201)+$ Serenade ${ }^{\circledR}(40 \mathrm{ml} / 201)$.

After the treatment, the fruits were stored on the shelves at room temperature and in the cold room at $10 \pm 1{ }^{\circ} \mathrm{C}$. Evaluations of FWL and color index were performed at $0,3,6,9$ and 12 days.

Fresh Weight Loss (FWL): It was determined by the difference between the initial and final weight in each evaluation period in both cold room and outside. The values were expressed as a percentage.

Color index: This evaluation was performed using the Color Quest XE colorimeter (HunterLab.). The color values were relative to the absolute ones in a perfect diffuse reflection. This measurement was done in some geometric conditions, defined in 1974 by the International Committee de l'éclairage (C.I.E)
(MINGUEZ-MOSQUERA et al., 1995). The assays were performed in three replicates, whose values were obtained according to previous methods (MASKAN, 2001).

Severity AACF1 (Lesion number): Effect of the treatments of the area below the progression curve of the disease spot number (AACF1) in the papaya postharvest as previously described (MORAES et al., 2008). In all the evaluation days, the number of spots of all the fruits was registered and the AAC was calculated by the above mentioned method. After statistical analysis revealed the relationship with each treatment and storage environment etc.

Severity AACF2 (Lesion diameter): Effect of the treatments of the area below the progression curve of disease spot size (AACF2) in papaya post-harvest. On a daily evaluation, the diameter of lesions on fruits was recorded to the first decimal place in centimeters using a ruler, and the AAC was calculated by the above method. After statistical analysis revealed the relationship with each treatment and storage environment etc.

For the disease severity, the both number of lesions and their diameter were daily recorded to calculate the area (AAC) was calculated (SHANER; FINNEY, 1977). The procedure for obtaining AACF 1 and AACF 2 are as follows. First, the number (F1) and size (F2) (lesion diameter) of all fruit stains were measured and recorded on the day of evaluation. Subsequently, as in the analysis of mass loss and color index, the mean was calculated as 3 fruits $\mathrm{x} 3$ groups for each treatment. Based on the calculated mean value on each valuation day, the AAC considers AAC1 to AAC4 by the following calculation formula, and the sum of them is taken as AACF1, AACF2; (evaluation 1+ evaluation 2) x 0.5 x 3 = AAC1, (evaluation 2+ evaluation 3 ) $\times 0.5 \times 3=$ $\mathrm{AAC} 2$, (evaluation $3+$ evaluation 4 ) $\times 0.5 \times 3=\mathrm{AAC} 3$, (evaluation $4+$ evaluation 5) $\times 0.5 \times 3=\mathrm{AAC} 4, \mathrm{AAC} 1+$ $\mathrm{AAC} 2+\mathrm{AAC} 3+\mathrm{AAC} 4=\mathrm{AACF}$. For this formula 0.5 represents the average of the two evaluations and 3 the number of evaluated fruits.

Disease incidence: Incidence was calculated as "the number of fruits with disease spots" / "total of fruits (9)", measured for each treatment on the final day of the evaluation.

Average Incidence: It is the average of 5 incidents calculated at each evaluation date.

In the analysis of diseases (AACF1, AACF2, Incidence and Mean Incidence), the following calculation formula was applied in the statistical analysis to clarify the difference; Square root of Y + 1.0 - SQRT $(Y+1.0)$. No transformation is done in color index analysis or mass loss

The data were submitted to analysis of variance 
and significance by the Tukey test. The means of evaluation periods and their interaction with the other treatments were adjusted by the regression analysis, both at $5 \%$ of probability using the Sanest program.

\section{Results and discussion}

The results of FWL of fruits indicated that the effects of treatments were observed in January (Samurai) and February (Samurai+Serenade; Euprooff; Euprooff ${ }^{\circledR}+$ Serenade ${ }^{\circledR}+$ Samurai). Additionally, the effects of cooling were found after 6 days of exposure (Tables 1-2). The index color was affected by seasonality and temperature over the year, however only the Samurai treatment have decreased this value in January for the $\mathrm{L}$ values. The $\mathrm{a}$ and $\mathrm{b}$ data indicated effects of Serenade and Euprooff treatments, as compared to the control (Tables 3-4). Low temperatures at $10^{\circ} \mathrm{C}$ have been shown as optimum conditions to storage papaya fruits and delay ripening, especially due to low ethylene production (AN et al., 1990).

Table 1. Fresh weight loss of papaya ‘Tainung 1' according to treatments and evaluation time. Brasília-DF, 2017/2018.

\begin{tabular}{cccc}
\hline \multirow{2}{*}{ TREATMENTS } & \multicolumn{3}{c}{ Fresh weight loss (\%) } \\
\cline { 2 - 4 } & DEC & JAN & FEB \\
\hline Control & $3.06 \mathrm{Ca}$ & $3.80 \mathrm{Bb}$ & $5.06 \mathrm{Aa}$ \\
Samurai & $3.10 \mathrm{Ba}$ & $4.50 \mathrm{Aa}$ & $4.70 \mathrm{Aab}$ \\
Serenade ${ }^{\circledR}$ & $2.73 \mathrm{Ca}$ & $4.40 \mathrm{Bab}$ & $5.23 \mathrm{Aa}$ \\
Euprooff ${ }^{\circledR}$ & $2.83 \mathrm{Ba}$ & $4.36 \mathrm{Aab}$ & $4.13 \mathrm{Abc}$ \\
Euprooff ${ }^{\circledR}+$ Serenade ${ }^{\circledR}+$ Samurai & $2.76 \mathrm{Ba}$ & $4.06 \mathrm{Aab}$ & $3.93 \mathrm{Ac}$ \\
Samurai+ Serenade ${ }^{\circledR}$ & $3.40 \mathrm{Ba}$ & $3.86 \mathrm{ABab}$ & $4.00 \mathrm{Ac}$ \\
Average & 2.98 & 4.16 & 4.50 \\
\hline CV $(\%)$ & \multicolumn{3}{c}{23.94} \\
\hline
\end{tabular}

Means followed by equal letters, uppercase in lines and lowercase in columns, are not significantly different according to Tukey test, $95 \%$ probability; $\mathrm{CV}=$ coefficient of variation.

Table 2. Fresh weight loss of papaya 'Tainung 1' according to evaluation time (days) and storage environment. Brasília-DF, 2017/2018.

\begin{tabular}{ccc}
\hline \multirow{2}{*}{ Storage time (days) } & \multicolumn{2}{c}{ Fresh weight loss (\%) } \\
\cline { 2 - 3 } & Room Temperature & Cold room \\
\hline 0 & $0.00 \mathrm{Ae}$ & $0.00 \mathrm{Ae}$ \\
3 & $1.64 \mathrm{Ad}$ & $1.55 \mathrm{Ad}$ \\
6 & $4.09 \mathrm{Ac}$ & $2.88 \mathrm{Bc}$ \\
9 & $7.05 \mathrm{Ab}$ & $4.42 \mathrm{Bb}$ \\
12 & $11.09 \mathrm{Aa}$ & $6.11 \mathrm{Ba}$ \\
\hline $\mathrm{CV}(\%)$ & & \\
\hline
\end{tabular}

Means followed by equal letters, uppercase in lines and lowercase in columns, are not significantly different according to Tukey test, $95 \%$ probability; $\mathrm{CV}=$ coefficient of variation. 
Table 3. Index color ( $\mathrm{L}$, a, and b values) of papaya 'Tainung 1' peels according to storage environment and evaluation time. Brasília-DF, 2017/2018.

\begin{tabular}{|c|c|c|c|c|c|c|c|c|c|}
\hline \multirow[t]{2}{*}{ Storage } & \multicolumn{3}{|c|}{$\mathrm{L}$} & \multicolumn{3}{|c|}{$\mathrm{a}$} & \multicolumn{3}{|c|}{$\mathrm{b}$} \\
\hline & DEC & JAN & FEB & DEC & JAN & FEB & DEC & JAN & FEB \\
\hline Room Temperature & $49.21 \mathrm{Ca}$ & $50.43 \mathrm{Ba}$ & $52.66 \mathrm{Aa}$ & $4.71 \mathrm{Ba}$ & $5.36 \mathrm{Ba}$ & $7.90 \mathrm{Aa}$ & $41.05 \mathrm{Ba}$ & $39.20 \mathrm{Ca}$ & $42.90 \mathrm{Aa}$ \\
\hline Cold room & $35.83 \mathrm{Cb}$ & $40.05 \mathrm{Bb}$ & $46.31 \mathrm{Ab}$ & $-8.16 \mathrm{Cb}$ & $-6.51 \mathrm{Bb}$ & $-5.27 \mathrm{Ab}$ & $29.54 \mathrm{Bb}$ & $30.47 \mathrm{Bb}$ & $37.41 \mathrm{Ab}$ \\
\hline $\mathrm{CV}(\%)$ & & 5.26 & & & 591.37 & & & 9.40 & \\
\hline
\end{tabular}

Means followed by equal letters, uppercase in lines and lowercase in columns, are not significantly different according to Tukey test, $95 \%$ probability; $\mathrm{CV}=$ coefficient of variation; L: lightness; a: green-red color; b: blue-yellow color.

Table 4. Index color (L, a, and b values) of papaya 'Tainung 1' peels according to treatments and evaluation time. Brasília-DF, 2017/2018.

\begin{tabular}{|c|c|c|c|c|c|c|c|c|c|}
\hline \multirow{2}{*}{ TREAT } & \multicolumn{3}{|c|}{$\mathrm{L}$} & \multicolumn{3}{|c|}{$\mathrm{a}$} & \multicolumn{3}{|c|}{$\mathrm{b}$} \\
\hline & DEC & JAN & FEB & DEC & JAN & FEB & DEC & JAN & FEB \\
\hline Control & $43.14 \mathrm{Cab}$ & $45.10 \mathrm{Bab}$ & $49.93 \mathrm{Aab}$ & $-2.8 \mathrm{Bb}$ & $1.74 \mathrm{Bb}$ & $2.64 \mathrm{Aa}$ & $35.33 \mathrm{Ca}$ & $33.48 \mathrm{Bb}$ & 41.45 Aab \\
\hline Samurai & 41.97 Bab & $43.22 \mathrm{Bc}$ & $48.37 \mathrm{Ab}$ & $-2.19 \mathrm{Bab}$ & $-1.91 \mathrm{Bb}$ & $0.17 \mathrm{Ab}$ & $34.20 \mathrm{Ba}$ & $31.80 \mathrm{Bc}$ & $37.55 \mathrm{Ac}$ \\
\hline Serenade ${ }^{\circledR}$ & $41.62 \mathrm{Cb}$ & 46.17 Bab & $50.32 \mathrm{Aa}$ & $-1.79 \mathrm{Cab}$ & $0.51 \mathrm{Ba}$ & $3.39 \mathrm{Aa}$ & $34.78 \mathrm{Ba}^{3}$ & $35.63 \mathrm{Bab}$ & $41.48 \mathrm{Aab}$ \\
\hline Euprooff ${ }^{\circledR}$ & $42.47 \mathrm{Cab}$ & $46.28 \mathrm{Ba}$ & $50.73 \mathrm{Aa}$ & $-1.20 \mathrm{Ca}$ & $0.91 \mathrm{Ba}$ & $2.15 \mathrm{Aa}$ & $35.90 \mathrm{Ba}$ & $37.09 \mathrm{Ba}$ & $43.04 \mathrm{Aa}$ \\
\hline $\begin{array}{c}\text { Euprooff }{ }^{\circledR}+ \\
\text { Serenade }{ }^{\circledR}+\text { Samurai }\end{array}$ & $42.46 \mathrm{Cab}$ & $46.28 \mathrm{Ba}$ & 49.17 Aab & $-0.9 \mathrm{Ba}$ & $0.35 \mathrm{Aa}-$ & $-0.67 \mathrm{Aab}$ & b35.70 Ba & $37.26 \mathrm{Ba}$ & $39.88 \mathrm{Abc}$ \\
\hline Samurai+ Serenade $\mathbb{}$ & $43.46 \mathrm{Ba}$ & $44.41 \mathrm{Bbc}$ & $48.39 \mathrm{Ab}$ & $-1.28 \mathrm{Aa}$ & $-1.55 \mathrm{Ab}$ & $0.17 \mathrm{Ab}$ & $35.84 \mathrm{Ba}^{3}$ & $33.73 \mathrm{Bbc}$ & $37.53 \mathrm{Ac}$ \\
\hline CV $(\%)$ & & 5.26 & & & 591.37 & & & 9.40 & \\
\hline
\end{tabular}

Means followed by equal letters, uppercase in lines and lowercase in columns, are not significantly different according to Tukey test, 95\% probability; $\mathrm{CV}$ = coefficient of variation; L: lightness; a: green-red color; b: blue-yellow color.

\section{Severity AACF1}

There were only two statistical significant combinations in the two Severity (AACF1 and AACF2), Season (DEC, JAN, FEB) X Local (Room temperature and Cold Room) and Season X Six treatments. Moreover, there were three combinations where statistically significant differences were found in the two incidences (Incidence and Mean of Incidence): Time X Place, Time X Treatment, Place X Treatment.
The number of spots analyzed (AACF1) relative to Local X Season (Table 5), showed a significant difference of February that was higher at room temperature. There was no significant difference in the cold room. Over the season, this value under cold room was lower than under room tempetarure, as reported in many studies in which the disease is lower under cooling conditions (SILVEIRA et al., 2005).

Regarding the time (DEC, JAN, FEB) X Six Treatments (Table 6), there was a significant increasing difference in February. In this month the Serenade ${ }^{\circledR}$ treatment reached the maximum value, whereas the Samurai the minimum. 
Table 5. Severities, AACF1 (Lesion number) and AACF2 (Lesion size), in papaya 'Tainung 1' according to storage environment and evaluation time. Brasilia DF, 2017/2018.

\begin{tabular}{ccccccc}
\hline \multirow{2}{*}{ Storage } & \multicolumn{3}{c}{ AACF1 } & \multicolumn{3}{c}{ AACF2 } \\
\cline { 2 - 7 } & DEC & JAN & FEB & DEC & JAN & FEB \\
\cline { 2 - 7 } Normal Temperature & $2.01 \mathrm{Ca}$ & $3.32 \mathrm{Ba}$ & $5.15 \mathrm{Aa}$ & $2.39 \mathrm{Ca}$ & $3.74 \mathrm{Ba}$ & $5.13 \mathrm{Aa}$ \\
Cold Room & $1.38 \mathrm{Ab}$ & $1.23 \mathrm{Ab}$ & $1.53 \mathrm{Ab}$ & $1.36 \mathrm{Ab}$ & $1.22 \mathrm{Ab}$ & $1.58 \mathrm{Ab}$ \\
\hline $\mathrm{CV}(\%)$ & & 25.41 & & & 19.23 \\
\hline
\end{tabular}

Means followed by equal letters, uppercase in lines and lowercase in columns, are not significantly different according to Tukey test, $95 \%$ probability; $\mathrm{CV}=$ coefficient of variation.

\section{Severity AACF2}

Regarding the lesion size of the analysis between Season $\mathrm{x}$ Place, in February was higher at room temperature. There was no significant difference in the cold room (Table 5). At all times, the number of spot size was low in cold room, as reported in many studies where the disease in fruits is lower under refrigerated conditions (SILVEIRA et al., 2005). Similarly, the Season X Treatment showed higher values in February in all treatments. And a significant difference between treatments was found in December and February.

Table 6. Severities, AACF1 (Lesion number) and AACF2 (Lesion size), respectively in papaya 'Tainung 1' according to treatments and time of evaluation. Brasilia DF, 2017/2018

\begin{tabular}{|c|c|c|c|c|c|c|}
\hline \multirow{2}{*}{ Treatments } & \multicolumn{3}{|c|}{ AACF1 } & \multicolumn{3}{|c|}{ AACF2 } \\
\hline & DEC & JAN & FEB & DEC & JAN & FEB \\
\hline Control & $1.68 \mathrm{Ba}$ & $1.90 \mathrm{Ba}$ & $3.83 \mathrm{Aab}$ & $1.81 \mathrm{Bab}$ & $2.47 \mathrm{Ba}$ & $3.72 \mathrm{Aab}$ \\
\hline Samurai & $1.31 \mathrm{Ba}$ & $2.09 \mathrm{ABa}$ & $2.42 \mathrm{Ac}$ & $1.49 \mathrm{Bb}$ & $2.35 \mathrm{Aa}$ & $2.88 \mathrm{Ab}$ \\
\hline Serenade ${ }^{\circledR}$ & $1.60 \mathrm{Ca}$ & $2.48 \mathrm{Ba}$ & 4.20 Aa & $1.76 \mathrm{Cab}$ & $2.66 \mathrm{Ba}$ & $3.86 \mathrm{Aa}$ \\
\hline Euprooff ${ }^{\circledR}$ & $1.93 \mathrm{Ba}$ & $2.66 \mathrm{ABa}$ & $3.25 \mathrm{Abc}$ & $1.96 \mathrm{Bab}$ & $2.82 \mathrm{Aa}$ & $3.29 \mathrm{Aab}$ \\
\hline Euprooff $\AA+$ Serenade $\AA+$ Samurai & $1.56 \mathrm{Ba}$ & $2.25 \mathrm{Ba}$ & $3.10 \mathrm{Abc}$ & $1.86 \mathrm{Bab}$ & $2.52 \mathrm{Ba}$ & $3.25 \mathrm{Aab}$ \\
\hline Samurai+ Serenade ${ }^{\circledR}$ & $2.09 \mathrm{Ba}$ & $2.30 \mathrm{Ba}$ & $3.22 \mathrm{Abc}$ & $2.39 \mathrm{Ba}$ & $2.32 \mathrm{Ba}$ & $3.22 \mathrm{Aab}$ \\
\hline
\end{tabular}

$$
\text { CV }(\%)
$$

Means followed by equal letters, uppercase in lines and lowercase in columns, are not significantly different according to Tukey test, $95 \%$ probability; $\mathrm{CV}=$ coefficient of variation

\section{Disease incidence}

Regarding the time (DEC, JAN, FEB) X storage location (room temperature and cold room), there was a significant difference in February, and those at room temperature than in cold room. In all the time (Table 7), as reported in many studies, the disease in fruits is lower under refrigerated conditions (SILVEIRA et al., 2005). The cooling is usually able to alleviate the effects of post-harvesting diseases in tropical fruits (STRANO et al., 2017).

Table 7. Incidence and Average of Incidence of papaya 'Tainung 1' according to storage environment and evaluation period. Brasilia DF, 2017/2018.

\begin{tabular}{ccccccc}
\hline \multirow{2}{*}{ Storage } & \multicolumn{3}{c}{ Incidence } & \multicolumn{3}{c}{ Average of incidence } \\
\cline { 2 - 7 } & DEC & JAN & FEB & DEC & JAN & FEB \\
\cline { 2 - 7 } Normal Temperature & $1.36 \mathrm{Ba}$ & $1.40 \mathrm{Aa}$ & $1.41 \mathrm{Aa}$ & $1.13 \mathrm{Ca}$ & $1.17 \mathrm{Ba}$ & $1.23 \mathrm{Aa}$ \\
Cold Room & $1.11 \mathrm{Bb}$ & $1.09 \mathrm{Bb}$ & $1.15 \mathrm{Ab}$ & $1.03 \mathrm{Bb}$ & $1.02 \mathrm{Cb}$ & $1.04 \mathrm{Ab}$ \\
\hline CV $(\%)$ & & 2.50 & & & 0.95 &
\end{tabular}

Means followed by equal letters, uppercase in lines and lowercase in columns, are not significantly different according to Tukey test, $95 \%$ probability; $\mathrm{CV}=$ coefficient of variation. 
Regarding the Time X Six treatments, as in other results, February obtained the maximum incidence value of the disease (Table 8). In December and January, the treatment of Samurai + Serenade ${ }^{\circledR}$ was higher than the control and Samurai

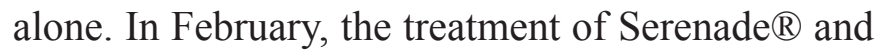
EUPROOFF® + Samurai + Serenade ${ }^{\circledR}$ were higher than the Samurai. Although the treatments have caused slightly effects depending on the season, the maximum value was found in Serenade ${ }^{\circledR}$ treatment in many cases, and the Samurai reached the minimum value. Perhaps the control was relatively good is affected by less physical damage due to the treatments. Physical damage such as scratches, cuts and abrasions are one of the main causes of disease (ROCHA, 2007). Treatments with less effect can increase the disease effects.
Regarding the incidence of the disease and the Storage site X Six treatments, there was a significant difference in the cold room for all treatments relative to room temperature (Table 5). No difference between Treatments was found at room temperature, but a significant difference was seen in the cold room. For example, Describing in descending order of numbers in the cold room, 1.18 (greater) in the Serenade ${ }^{\circledR}$ Treatment, 1.15 in the EUPROOFF ${ }^{\circledR}$ Treatment, 1.13 in the EUPROOFF ${ }^{\circledR}+$ Samurai + Serenade ${ }^{\circledR}$ Treatment, 1.13 in the Treatment of Samurai + Serenade ${ }^{\circledR}, 1.10$ in Witness, 1.01 in Samurai treatment (Table 9). In other words, the use of Samurai alone is the least occurrence, and all other treatments are that diseases occur more than witness. However, even if he used the Samurai alone, the disease occurred. This means that the occurrence of disease was delayed. Regarding papaya at room temperature, it can be said that there is almost no effect of the treatment. Only when compared in the cold room can you say that the Samurai treatment is effective.

Table 8. Incidence and Average of incidence of papaya 'Tainung 1' according to treatments and time of evaluation. Brasilia DF, 2017/2018.

\begin{tabular}{ccccccc}
\hline \multirow{2}{*}{ Treatments } & \multicolumn{3}{c}{ Incidence } & \multicolumn{3}{c}{ Average of incidence } \\
\cline { 2 - 7 } & DEC & JAN & FEB & DEC & JAN & FEB \\
\hline Control & $1.19 \mathrm{Bc}$ & $1.20 \mathrm{Bc}$ & $1.30 \mathrm{Aab}$ & $1.08 \mathrm{Bbc}$ & $1.09 \mathrm{Bb}$ & $1.17 \mathrm{Aa}$ \\
Samurai & $1.18 \mathrm{Ac}$ & $1.21 \mathrm{Ac}$ & $1.20 \mathrm{Ac}$ & $1.04 \mathrm{Bd}$ & $1.08 \mathrm{Ab}$ & $1.10 \mathrm{Ac}$ \\
Serenade ${ }^{\circledR}$ & $1.23 \mathrm{Bbc}$ & $1.30 \mathrm{Aa}$ & $1.33 \mathrm{Aa}$ & $1.08 \mathrm{Cbc}$ & $1.11 \mathrm{Ba}$ & $1.17 \mathrm{Aa}$ \\
Euprooff ${ }^{\circledR}$ & $1.26 \mathrm{Aab}$ & $1.28 \mathrm{Aab}$ & $1.28 \mathrm{Aab}$ & $1.09 \mathrm{Bb}$ & $1.12 \mathrm{Aa}$ & $1.13 \mathrm{Ab}$ \\
Euprooff $\AA+$ Serenade ${ }^{\circledR}+$ Samurai & $1.21 \mathrm{Bbc}$ & $1.23 \mathrm{Bbc}$ & $1.33 \mathrm{Aa}$ & $1.07 \mathrm{Bc}$ & $1.08 \mathrm{Bb}$ & $1.12 \mathrm{Ab}$ \\
Samurai+ Serenade ${ }^{\circledR}$ & $1.30 \mathrm{Aa}$ & $1.23 \mathrm{Bbc}$ & $1.25 \mathrm{Bbc}$ & $1.13 \mathrm{Aa}$ & $1.08 \mathrm{Bb}$ & $1.12 \mathrm{Ab}$ \\
\hline CV $(\%)$ & & 2.50 & & & 0.95 &
\end{tabular}

Means followed by equal letters, uppercase in lines and lowercase in columns, are not significantly different according to Tukey test, $95 \%$ probability; $\mathrm{CV}=$ coefficient of variation.

Table 9. Incidence and Average of incidence papaya 'Tainung 1' according to treatments and storage environment (Room Temperature and Cold Room). Brasilia DF, 2017/2018.

\begin{tabular}{ccccc}
\hline \multirow{2}{*}{ Treatments } & \multicolumn{2}{c}{ Incidence } & \multicolumn{2}{c}{ Average of incidence } \\
\cline { 2 - 5 } Control & Room Temperature & Cold Room & Room Temperature & Cold Room \\
\cline { 2 - 5 } Samurai & $1.37 \mathrm{Aa}$ & $1.10 \mathrm{Bc}$ & $1.19 \mathrm{Aa}$ & $1.03 \mathrm{Bb}$ \\
Serenade ${ }^{\circledR}$ & $1.38 \mathrm{Aa}$ & $1.01 \mathrm{Bd}$ & $1.14 \mathrm{Ab}$ & $1.00 \mathrm{Bc}$ \\
Euprooff ${ }^{\circledR}$ & $1.40 \mathrm{Aa}$ & $1.18 \mathrm{Ba}$ & $1.20 \mathrm{Aa}$ & $1.05 \mathrm{Ba}$ \\
Euprooff ${ }^{\circledR}+$ Serenade ${ }^{\circledR}+$ Samurai & $1.40 \mathrm{Aa}$ & $1.15 \mathrm{Bab}$ & $1.19 \mathrm{Aa}$ & $1.04 \mathrm{Bab}$ \\
Samurai+ Serenade ${ }^{\circledR}$ & $1.38 \mathrm{Aa}$ & $1.13 \mathrm{Bbc}$ & $1.15 \mathrm{Ab}$ & $1.03 \mathrm{Bb}$ \\
\hline $\mathrm{CV}(\%)$ & $1.40 \mathrm{Aa}$ & $1.13 \mathrm{Bbc}$ & $1.18 \mathrm{Aa}$ & $1.03 \mathrm{Bab}$ \\
\hline \multicolumn{2}{c}{2.50} & \multicolumn{3}{c}{0.95}
\end{tabular}

Means followed by equal letters, uppercase in lines and lowercase in columns, are not significantly different according to Tukey test, $95 \%$ probability; $\mathrm{CV}=$ coefficient of variation. 


\section{Average of incidence}

In relation to the period (DEC, JAN, FEB) $\mathrm{X}$ Storage location (Ambient Temperature and Cold Room) and mean incidence, there was a significant difference in the value of February was higher at room temperature than in the cold room (Table 7). In all cases, the cold room number was low, as reported in many studies that fruit disease is lower under refrigerated conditions (SILVEIRA et al., 2005). In relation to Time X Six Treatments and the average incidence of the disease, as in other results, February obtained the maximum value. As a difference between treatments, it was judged that there was difference at any time. In December, the Treatment of Samurai + Serenade ${ }^{\circledR}$ was maximum value of 1.13 and the Treatment of Samurai was a minimum value of 1.04. In January, Serenade ${ }^{\circledR}$ treatment (1.11) and EUPROOFF® (1.12) were maximum values, the control (1.20), Samurai (1.21), EUPROOFF® + Samurai + Serenade ${ }^{\circledR}(1.08)$ and Samurai + Serenade ${ }^{\circledR}(1.08)$ were minimal values. In February, the control (1.17) and Serenade (1.17) were maximum values and the Samurai (1.10) was the minimum value (Table 8).

Although the treatment that takes the minimum value is slightly different depending on the season, the maximum value is found in Serenade ${ }^{\circledR}$ treatment alone in many cases, and the treatment value of Samurai alone is always included in the minimum value.

Regarding Storage Location X Six Treatments (Table 9), there was no significant difference in Treatment was found at room temperature, but a significant difference was seen in the cold room. For example, descending order numbers in the cold room, 1.05 (higher) Serenade ${ }^{\circledR}, 1.04$ in EUPROOFF ${ }^{\circledR}, 1.03$ in the EUPROOFF ${ }^{\circledR}+$ Samurai + Serenade ${ }^{\circledR}$ Treatment, 1.03 in the control, 1.03 in the Treatment of Samurai + Serenade ${ }^{\circledR}, 1.00$ (lower) in the Samurai alone (Table 5). In other words, using Samurai alone is most effective, and all other treatments are that diseases occur equal to or more than control.

These values are the average of the incidences observed in all evaluation dates. The diseases that occur once will never be cured, so the higher value means that the disease occurred earlier. One could say that using Samurai alone was effective in slowing down the occurrence of the disease. When comparing Incidence and Mean incidence scores, although it is almost the same result in the cold room, they show that values were low with samurai treatment and EUPROOFF® + Samurai + Serenade ${ }^{\circledR}$ treatment at room temperature. However, on the last day of evaluation (day 12), most diseases will occur at room temperature and cold room in all treatments.

\section{Conclusions}

Samurai treatment showed control efficiency, and the other treatments did not present control.

No synergistic effect was observed mixing the products. In most cases, the disease occurred more than witnessed, except the use of the Samurai alone.

It was found that using Samurai alone in storage in the cold room preserved the occurrence and progression of diseases.

\section{References}

AMARANTE, C.; BANKS, N.H; GANESH, S. Relationship between character of skin cover of coated pears and permeance to water vapor and gases. Postharvest Biology and Technology, Amsterdam, v.21, n.3, p.291-301, 2001.

AN, J.F.; PAULL R.E. Storage temperature and ethylene influence on ripening of papaya fruit. Journal of the American Society for Horticultural Science, Alexandre, v.115, n.6, p.949-953, 1990.

CHITARRA M.I.F; CHITARRA A.B. Pós-colheita de frutos e hortaliças: fisiologia e manuseio. Lavras: UFLA, 2005. 785p.

CIA, P. Avaliação de agentes bióticos e abióticos na indução de resistência e no controle pós-colheita da antracnose (Colletotrichum gloeosporioides) em mamão (Carica papaya). 2005. Tese (Doutorado em Fitopatologia) - Escola Superior de Agricultura Luiz de Queiroz, Piracicaba, 2005.

FAOSTAT. Crops and livestock products. Rome, 2018. Disponível em: http://www.fao.org/faostat/en/\#data/TP. Acesso em: 9 mar. 2018.

FOLEGATTI, M.I.S.; MATSUURA, F.C.A.U. Mamão: pós-colheita. Brasília: Embrapa , 2002. (Informação Tecnológica)

JACOMINO, A.P.; KLUGE, R.A. BRACKMANN, A.; CASTRO, P.R.C. Amadurecimento do mamão com 1-metilciclopropeno. Scientia Agrícola, Piracicaba, v.59, n.2, p.303-308, 2002. 
KRETZCHMAR, A.A.; VALDEBENITO-SANHUEZA, R.M. Avaliação de Bacillus subtilis e Bacillus thuringiensis no controle de Penicillium expansum em frutos de macieira após colheita. In: REUNIÃO BRASILEIRA SOBRE CONTROLE BIOLÓGICO DE DOENÇAS DE PLANTAS, 4., 1991, Campinas. Resumo [...]. Campinas: Embrapa-CNPDA, 1991.

KRETZCHMAR, A.A. Controle biológico de patógenos que ocorrem em pós-colheita em fruteiras. In: REUNIÃO BRASILEIRA SOBRE CONTROLE BIOLÓGICO DE DOENÇAS DE PLANTAS, 3., 1989, Piracicaba. Anais [...]. Piracicaba, 1989.

MASKAN, M. Kinetics of color change of kiwifruits during hot air and microwave drying. Journal of Food Engineering, Essex, v.48, p.169-175, 2001.

MINGUEZ-MOSQUERA, M. I.; REJANO-NAVARRO, L.; GANDUL-ROJAS, B.;SANCHEZ-GÓMEZ, A. H., GARRIDO-FERNANDEZ, J. Color-pigment correlation in virgin olive oil. Journal of the American Oil Chemists' Society, Chicago, v.72, n.12, p.1425-1429, 1995.

MORAES, W.S; ZAMBOLIM, L.; LIMA, J.D. Quimioterapia de banana 'prata anã' no controle de podridões em pós-colheita. Arquivos do Instituto Biológico, São Paulo, v.75, n.1, p.79-84, 2008.

NERY-SILVA, F.A.; MACHADO, J.C.; LIMA, L.C.O.; RESENDE, M.L.V. Controle químico da podridão peduncular de mamão causada por Colletotrichum gloeosporioides. Ciência e Agrotecnologia, Lavras, v.25, n.3, p.519-524, 2001.

OLIVEIRA, A.A.R. Mamão fitossanidade. Brasília (DF): Embrapa Comunicação para Transferência de Tecnologia, 2000. p.13-14.

PUSEY, P.L.; WILSON, C.L.; HOTCHKISS, M.W.; FRANKLIN, J.D. Compatibility of Bacillus subtilis for postharvest control of peach brown rot with commercial fruit waxes, dicloran, and cold-storage conditions. Plant Disease, Saint Paul, v.70, p.587-590, 1986.
ROCHA, R.H.C.; MENEZES, J.B.; NASCIMENTO, S.R.C.; NUNES, G.H.S. Qualidade do "Mamão Formosa" submetido a diferentes temperaturas de refrigeração. Revista Caatinga, Mossoró, v.20, n.1, p.75-80, 2007.

ROMEIRO, R.S. Controle biológico de doenças de plantas: fundamentos. Viçosa: UFV, 2007. 296 p.

SANHUEZA, R.M.V.; BORSÓI, M. Métodos para seleção de antagônicos a Penicillum expansum afetando maçãs em condições de laboratório. In: REUNIÃO BRASILEIRA SOBRE CONTROLE BIOLÓGICO DE DOENÇAS DE PLANTAS, 4, 1991, Campinas. Anais [...]. Campinas: Embrapa-CNPDA, 1991.

SHANER, G.; FINNEY, R.E. The effect of nitrogen fertilization on the expression of slow-mildewing resistance in Knox wheat. Phytopathology, Saint Paul, v.67, n.8, p.1051-1056, 1977.

SILVA, O.F.; SOARES, A.G. Recomendações para prevenção de perdas pós- colheita do mamão. Rio de Janeiro: Embrapa Agroindústria de Alimentos, 2001. 20p.

SILVEIRA, N.S.S.; MICHEREFF, S.J.; SILVA, I.L.S.S.; OLIVEIRA, S.M.A. Doenças fúngicas pós-colheita em frutas tropicais: patogênese e controle. Caatinga, Mossoró, v.18, n.4, p.283-299, 2005.

STRANO, M.C.; ALTIERI, G.; ADMANE, N., GENOVESE, F.; DI RENZO, G.C. Advance in citrus postharvest management: diseases, cold storage and quality evaluation. In: GILL, H.; GARG, H. Citrus pathology. London: In TechOpen, 2017. p.139-159.

ZAMBOLIM, L.; COSTA, H.; VENTURA, J.A.; VALE, F.X.R. Controle de doenças pós-colheita de frutas tropicais. In: ZAMBOLIM, L. (Ed.). Manejo integrado: fruteiras tropicais - doenças e pragas. Viçosa: Universidade Federal de Viçosa, 2002. p.443-511. 